\title{
Manufacture and Use of Bone Points from Early Neolithic Colle Santo Stefano, Abruzzo, Italy
}

\author{
Alexandra Legrand \\ CNRS-UMR 7055 \\ Nanterre, France
}

Giovanna Radi

University of Pisa

Pisa, Italy

The site of Colle Santo Stefano in the Fucine Basin (Abruzzo, Italy) represents the central Adriatic phase of the Early Neolithic ceramica impressa (impressed ware) complex, which dates to the first half of the 6th millennium CAL B.C. This paper focuses on bone points, which comprise the main category of tools present (189 out of 272 total tools). A comprehensive study including technological and use-wear analyses resulted in the identification of two main types of points which were used mainly to work on or with plant fibers, probably in basket-making.

\section{Introduction}

The Early Neolithic site of Colle Santo Stefano is located in the area of Pozzo di Forfora, southeast of the village of Ortucchio in the Fucine Basin (Abruzzo, Italy) (FIG. I). Since 1988, excavations have been conducted on ca. $250 \mathrm{sq}$ $\mathrm{m}$, though the settlement as a whole may cover at least one hectare. An inhabited area has been revealed that relates to the central Adriatic phase of the Early Neolithic ceramica impressa (impressed ware) complex, with connections to southern Italy (Radi 1991, 1996; Radi and Danese 2003). The homogeneity of the deposit identified during the excavations, confirmed by sediment analysis (Radi et al. 2001), suggests a rapid accumulation of sediments essentially due to human action. The deposit thus possibly represents one occupation of the village during the Early Neolithic.

Thanks to careful excavation of the successive layers by the décapages method and mapping of finds, the study of lithic and ceramic materials has allowed us to recognize three different phases dating to the first half of the 6th millennium CAL B.C. The early phase is represented by a paved structure that spreads over $90 \mathrm{sq} \mathrm{m}$. The middle phase consists of the depression of a small channel oriented $\mathrm{E}-\mathrm{W}$, possibly a fence foundation. In the northern area of this channel, excavations have revealed a fireplace covered by quern fragments and another depression containing a small zoomorphic vessel. The final phase is badly preserved and has been disturbed by modern ploughing. Eight radiocarbon dates (seven of which are AMS) suggest ranges of 5810-5640 CAL B.C. (Sample LTL60A: $6843 \pm 40$ B.P. from cut 13) for the early phase, and 5630-5460 CAL B.C. (Sample LTL57A: $6579 \pm 60$ B.P. from cut 3) for the final phase. It is worthwhile to note that the dates of the final phase match those now considered to be the oldest for the Early Neolithic in this region (Skeates and Whitehouse 1994). Consequently, the new data from Colle Santo Stefano span the development of Neolithic culture in the Fucine Basin.

Both the ceramics and lithics show little variation in the early and middle phases, suggesting minimal change in life habits and economic preferences, though variation increases during the latest phase (Fabbri 2006). Ceramic production shows some features characteristic of the ceramica impressa cultural complex, such as decorated ovoid pots and wide undecorated bowls. On the other hand, incised decoration (zig-zag motifs) might be considered specific to Colle Santo Stefano ceramic production, although it is also found in the north-central Adriatic. Ceramic production also has a component (with cardinm-impressed pottery, rocker and microrocker decoration, and vessels with anthropomorphic protomes on the rim) which is similar to 


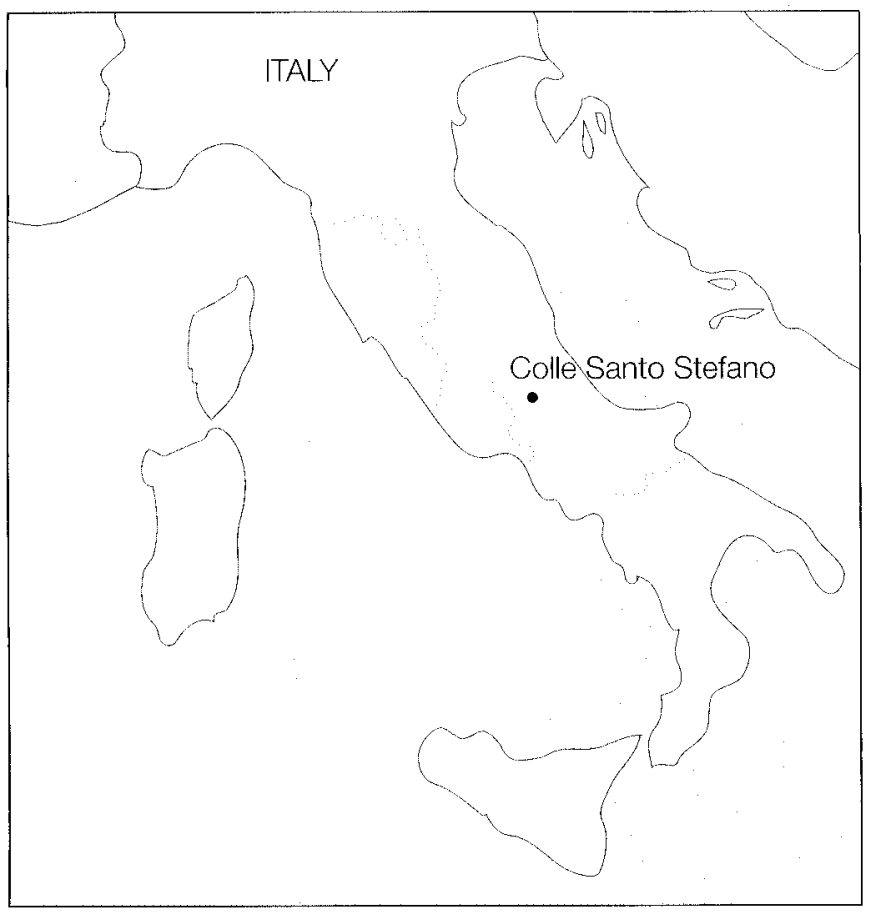

Figure 1. Location of the village of Colle Santo Stefano.

southern impressed ware, specifically of the Guadone phase identified in the Apulian region.

The lithic industry comprises a rich assemblage with various and specialized tools (Radi et al. 2001). This assemblage has some features similar to other industries in central Italy that have a Mesolithic component: blade debitage, microburin technique, specialized tools such as truncations and trapezes, and the use of obsidian (Radi 1991, 1996; Radi and Danese 2003).

During the course of site occupation, material culture changed recognizably both in the lithic industry, ending with the specialization of debitage techniques and the standardization of tool morphologies, and in the ceramic industry, which exhibited different cultural influences. It is probable that this development was permitted by greater stability and a better quality of life within the village than before, as shown by the intensification of primary economic activities and expanding contact with other groups.

The economy of Colle Santo Stefano was typically Neolithic, based on farming, animal husbandry, and infrequent hunting and fishing. Caprines are the most common taxa at Colle Santo Stefano ( $43 \%$ of the identified fauna), followed by pig (Sus scrofa domesticus L., 11.5\%), and catthe (Bos taumis L., 6.5\%) (Radi and Wilkens 1989; Wilkens 1991). Paleobotanical analysis indicates the cultivation of emmer (Triticum dicoccum L.) and einkorn wheat (Triticum monococcum L.) (Castiglioni and Rottoli 2003). The pres- ence of numerous sickle-blade elements and grinding slabs also suggest that grain agriculture was practiced (Radi et al. 2001).

\section{The Bone Tools}

Few studies have been conducted on Early Neolithic bone industries in Italy, which limits our knowledge of this type of production, even though it is as essential as the ceramic and lithic industries to our understanding of the economy, technology, and cultural choices of Neolithic communities. Thus, our first goal was to document the bone industry and to provide new data for the study of the processes of neolithization in Italy, as the ceramica impressa complex is considered to be the earliest cultural feature of the Neolithic period in the western Mediterranean. In this context, the site of Colle Santo Stefano provides a good starting point for research in the central Adriatic region, with a total of 272 bone artifacts coming from the whole excavated area. This collection includes 189 points, 13 edged tools, 13 ornaments, 1 adze, 4 pieces of manufacturing waste, and 52 undetermined fragments of worked bone (Fugazzola Delpino, Pessina, and Tiné 2002: 521). Fabiana Coli (2002) examined part of this assemblage previously analyzing typology and technology, and noted that similar tools were recovered in the Early Neolithic level at Grotta dei Piccioni (Cremonesi 1976: fig. 18 ) and in the contemporary village of Maddalena di Muccia (Lollini 1991: 57). The study presented here focuses on bone points for two reasons. First, their great number in comparison to other bone tool categories ( 189 out of 272 ) raises the question of the function of the site and the place of these tools within this community. Second, a general overview of the bone point assemblage shows that two morphological categories (Type IV-A and Type IV-B) indicate different manufacturing techniques, different degrees of work investment, and variable curation. Thus, it was useful to investigate whether or not these two groups differed in function, and a detailed analysis of manufacture and use-wear traces was undertaken.

\section{Selection of Raw Material}

Long bone was the main raw material exploited to manufacture points (188 out of 189) and edged tools at Colle Santo Stefano. Antler (Cervus elaphus L.) was used less frequently than bone; only one point was made from this raw material. Teeth, in particular pig tusks, were mainly used to make ornaments (9 out of 13 specimens). Concerning the species and the skeletal elements selected, identification was sometimes difficult because of the fragmentary nature of the material ( $15 \mathrm{I}$ out of 189 specimens are incomplete) and the high proportion of points made from splinters 
Table 1. Raw material exploited in the production of bone points.

\begin{tabular}{|llllllll|}
\hline & Caprine & Cenvid & Chamois & Suid & $\begin{array}{l}\text { Small } \\
\text { ruminant }\end{array}$ & Large \\
maminant & Total no. \\
\hline Metapodial & 3 & 0 & 0 & 0 & 10 & 0 & 13 \\
Tibia & 1 & 0 & 0 & 0 & 0 & 0 & 1 \\
Femur & 0 & 0 & 1 & 0 & 0 & 1 & 2 \\
Fibula & 0 & 0 & 0 & 0 & 2 & 0 & 2 \\
Humerus & 0 & 0 & 0 & 0 & 1 & 0 & 1 \\
Vertebra & 0 & 0 & 0 & 1 & 0 & 0 & 1 \\
Antler & 0 & 1 & 0 & 0 & 0 & 0 & 1 \\
Long bone & 0 & 0 & 0 & 0 & 31 & 2 & 33 \\
Total no. & 4 & 1 & 1 & 1 & 44 & 3 & 54 \\
\hline
\end{tabular}

which have no diagnostic anatomical characteristics preserved. The most commonly used raw material, however, derives from long bones, especially the metapodials, of animals herded by the site inhabitants (TABLE I).

\section{Bone Point Typology and Manufacturing Techniques}

Bone point typology was established according to the nature of the segmentation of the raw material (how bones were broken into blanks for use), and by the conservation and the transformation of anatomical characteristics such as the epiphyses (Choyke and Schibler 2007; Legrand 2007; Schibler 1981; Sidéra 1996, 2000). With the exception of tools made from whole bones for which no segmentation was necessary, we distinguish between longitudinal and transverse blanks. This typology forms the foundation of our work and links technological and functional analyses to the identified types of tools, with the aim of revealing the relationship between morphology, technique, and function. Only 96 of 189 points were complete enough to be classified into one of four types.

Before presenting these types, it is important to review the different manufacturing techniques employed by Neolithic peoples and the traces that these techniques leave on the surface of a tool. Indirect percussion was employed to divide the long bones longitudinally in halves or in quarters. When this technique is associated with grooving to finish cutting the bone, well-known striations with a Vprofile characteristic of grooving are observed. Unlike indirect percussion and grooving, direct percussion produces splinters of various sizes with irregular and asymmetrical sides (Camps-Fabrer and D'Anna 1977; Christidou 1999; ETTOS 1985; Sidéra 1993, 2004). No traces of impact are observable on these splinters. Only the evidence of shaping, which is often localized on the distal end of the tool, allows us to distinguish these tools from splinters produced as a by-product of marrow extraction.

Two main techniques of shaping can be identified: grinding and shaving. Shaving striations appear as bundles of deep, long, regular, continuous, and parallel marks as- sociated with bundles of thinner striations (Campana 1989; Christidou 1999, 2004; Newcomer 1974; Peltier 1986; Semenov 1964; Sidéra 1993). In certain cases, when the preservation of the surface is not good enough or when different traces overlap, the identification of the technique employed is difficult with the naked eye or with a stereomicroscope. Even the orientation of the striation can no longer be considered an efficient criterion. Recourse to higher magnifications $(100 \times$ and $200 \times)$ provided by a metallographic microscope appears to solve this problem (Christidou 2004; Legrand 2007). Additional criteria can then be taken into account such as the aspect of the edges and the bottoms of the striations. Edges of grinding striations are curved, and their bottoms are rough. In the case of the shaving, the edges are straight and the bottoms show very thin striations. These features can appear differently depending on the stone tool used and the texture of the grinding stone (Campana 1989; Christidou 2004).

\section{Bone Point Types}

Type I includes points made from whole bones. Three fragments of points, including two made from fibulae of small ruminants and one from an undetermined bone, fall into this type (FIG. 2A). In all cases, the morphology of the bone is preserved. Grinding was used to shape and reshape the distal ends of these tools.

Type II includes points made from transverse blanks of bone. Two fragments of points have been classified as this type. The first one was made from a caprine metacarpal by direct percussion (FIG. 2B). A part of the diaphysis of the bone and the proximal epiphysis are preserved. The distal end, partially fragmented, was shaped by grinding. The second point is made from a spinous process of a suid vertebra. The bone reduction technique is undetermined, but grinding and shaving were combined to shape the distal and the middle parts of the tool. No reshaping traces have been identified on either artifact.

Type III includes points made from longitudinal blanks of long bones with epiphyses partially preserved. Ten 


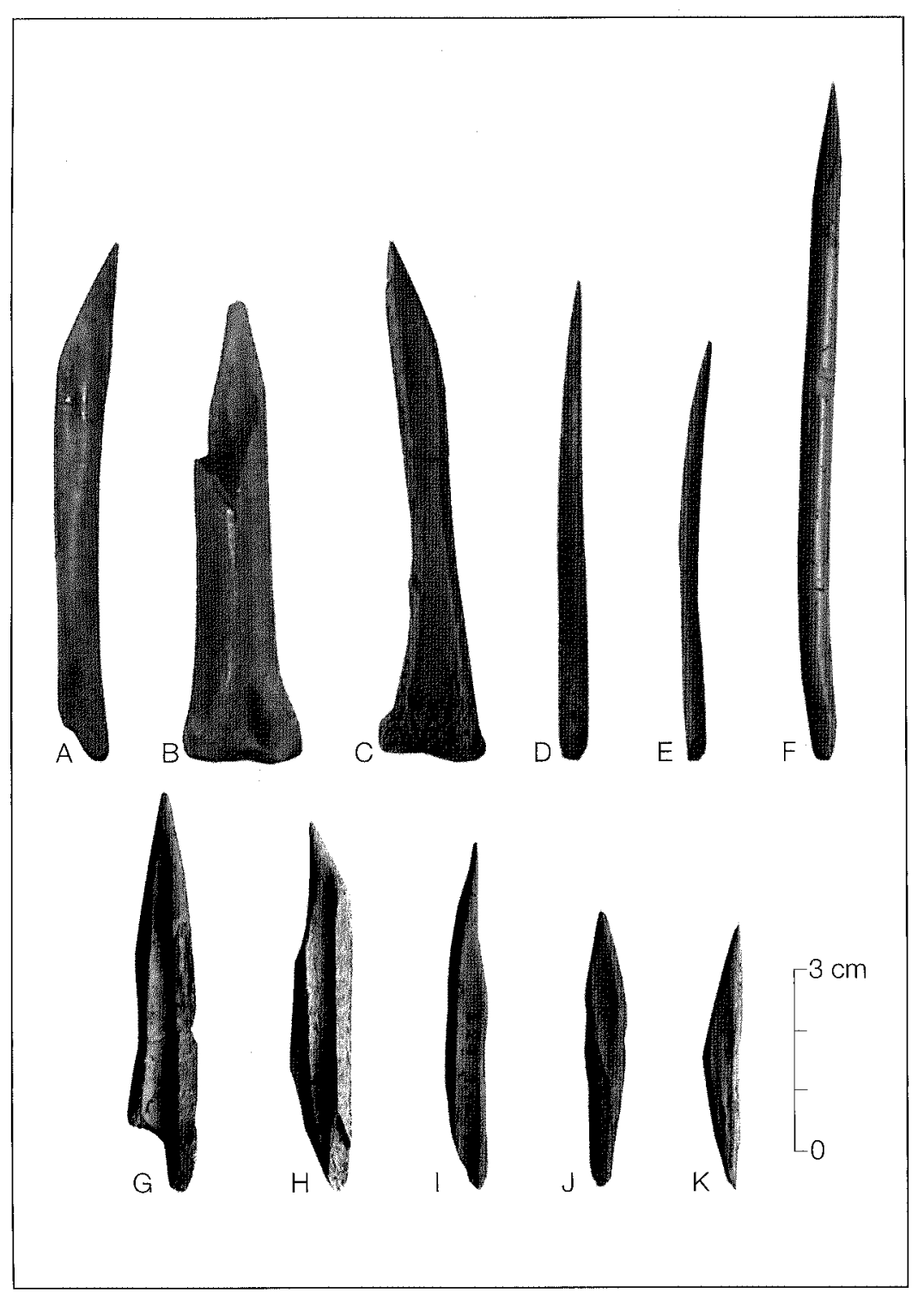

Figure 2. Bone point typology. A) Type I; B) Type II; C) Type III; D-F) Type IV-A; G-K) Type IV-B. Photographs by Alexandra Legrand.

points, including three made from metapodials, fall into this type (FIG. 2C). The bone is unidentified for the seven remaining points. Five complete tools are between 37 and $97 \mathrm{~mm}$ long (average: $65.4 \mathrm{~mm}$ ), have a maximum width between 5 and $8 \mathrm{~mm}$ (average: $6.4 \mathrm{~mm}$ ), and a thickness between 3.5 and $5 \mathrm{~mm}$ (average: $4.2 \mathrm{~mm}$ ). The section of the middle part is mainly crescent shaped $(\mathrm{n}=5)$ but can also be rectangular $(n=3)$ or circular $(n=2)$. Bone reduction techniques are not well understood for this type of point because of the absence of technical traces and manufacturing waste, but indirect percussion $(\mathrm{n}=2)$ and grooving $(n=1)$ have been identified. The lack of manufacturing waste within the Colle Santo Stefano bone industry (only four pieces were identified) may be explained by the fact that bone tool manufacturing took place in another part of the site (as yet unexcavated) or in an area outside the village. In the latter case, bone artifacts would have been brought into the village already finished. Concerning the shaping techniques employed, grinding was most commonly used $(\mathrm{n}=5)$ to shape the distal end, the middle part, or the entire length of the tool. Shaving striations have been observed on the middle and/or the proximal parts of two points. Finally, both techniques were combined on two points to shape the distal or proximal parts. For one point, the shaping technique is undetermined. In all cases, the degree of transformation of the blank as de- 
fined by Danielle Stordeur (1978) is low since the morphology of the bone is still preserved. Reshaping striations from grinding or shaving have been observed on two tips.

Type IV is the most common type $(\mathrm{n}=81)$ and includes points made from longitudinal blanks of bones without the epiphyses. They are mainly made from blanks which have no diagnostic anatomical characteristics (such as the epiphyses preserved), and which derive from small or large ruminant long bones $(n=79)$ including metapodials, femurs, humeri, tibias, and also from a rib $(\mathbf{n}=1)$ and an antler $(\mathrm{n}=1)$. Two point morphologies can be distinguished within this type: points made from a regular segment (Type IV-A, of which there are 45), and points made from an irregular segment (Type IV-B, of which there are 36). The main difference between these two groups is the degree of shaping of the blank, which is high for Type IV$A$ and low for Type IV-B.

In Type IV-A, the morphology of the bone is completely modified (FIG. 2D-F). The total length of the complete points (18 out of 45 points) is between 11 and $107 \mathrm{~mm}$ (average: $63.55 \mathrm{~mm}$ ), the maximum width is between 3.5 and $18.5 \mathrm{~mm}$ (average: $6.64 \mathrm{~mm}$ ), and the thickness is between 2.5 and $7 \mathrm{~mm}$ (average: $4.08 \mathrm{~mm}$ ). The section of the middle part is mainly circular $(\mathrm{n}=17)$, but may also be crescent shaped $(\mathrm{n}=9)$, rectangular $(\mathrm{n}=11)$, oval $(\mathrm{n}$ $=4)$, square $(\mathrm{n}=3)$, or triangular $(\mathrm{n}=1)$. The bone reduction techniques employed are undetermined because of the absence of technical traces which were probably covered over by shaping, except in two cases where grooved striations were observed. Moreover, we suggest that the point made from antler was manufactured by the groove and splinter technique which is best for extracting a long and a regular blank such as the one required to manufacture this tool $(94 \mathrm{~mm}$ long, $4 \mathrm{~mm}$ wide, and $3.5 \mathrm{~mm}$ thick). Grinding striations were observed on the middle parts of 17 points, while shaving striations have been recognized on the distal and/or the middle parts of nine points. Both techniques were identified on the middle of the tool or the entire length of eight artifacts. On the remaining 11 points, the shaping technique was undetermined. Reshaping traces were observed on 13 points. Shaving was preferentially employed to reshape the tips of these points (10 out of 13 ).

Type IV-B points are made from splinters (FIG. 2G-K). The total length of the complete points (6 out of 36 points) is between 49 and $90.5 \mathrm{~mm}$ (average: $67.2 \mathrm{~mm}$ ), the maximum width is between 4 and $14 \mathrm{~mm}$ (average: 9.3 $\mathrm{mm}$ ), and the thickness is between 3 and $8.5 \mathrm{~mm}$ (average: $4.9 \mathrm{~mm}$ ). The section of the middle part is mainly crescent shaped $(n=26)$, but may also be rectangular $(n=4)$, circular $(\mathrm{n}=1)$, oval $(\mathrm{n}=1)$, or square $(\mathrm{n}=1)$. In three cas- es, the morphology of the section could not be defined because of the fragmentation of the tool. The degree of shaping is low; the entire length of the tool was never shaped. The distal or middle parts of the points were shaped by grinding $(n=19)$, by shaving $(n=7)$, or by a combination of both techniques $(n=5)$. In five cases, the technique is unidentified. Only one point shows reshaping traces on its tip.

These two groups show various differences in terms of morphology and dimensions. In contrast to the points made from splinters, the morphology of the Type IV-A points consists of a thin and symmetrical blank with straight edges tapering to the tip. As we have little data about the bone reduction techniques employed to manufacture these points and no manufacturing waste, no link can be established between the technical investment required and the schema opératoire. Were bone reduction techniques such as grooving used, which would permit the manufacture of long thin blanks? Or, was the technical investment greater during the shaping phase? These two questions are not necessarily contradictory, but if we consider the localization and intensity of the shaping, the shaping phase appears especially important and required more effort. It also must be stressed that these formally-worked points are more often reshaped than the points made from splinters. This is interesting if we consider the maintenance of bone tools made by the inhabitants of Colle Santo Stefano. The formally-worked points, which would have required a longer working time and special skill, were carefully kept in good condition in order to remain efficient. Thus, they could have played a major role within the craft activities of the village and been of value to their owners (Choyke 2006; Dobres 2000; Le Dosseur 2006). The question is now whether or not the morphology of these points can be linked to their function, assuming that all the formally-worked points shared the same function.

\section{Use-Wear Analysis}

The frequency of points within the Colle Santo Stefano bone assemblage led us to undertake a combined macroand microscopic examination using a stereomicroscope (1-64 $\times$ magnification) and a metallographic microscope $(100 \times$ magnification). Macroscopic analysis is not always reliable for precisely interpreting the function of the points. Indeed, macroscopic wear observed on the active ends of points, generally smoothing, shows little difference from one point to another and thus does not reveal the nature of the worked material or the use of the tool. We have thus conducted a functional analysis based on several macro- and micro-criteria employed by different scholars working on bone functional analyses (Buc and Loponte 
2007; Campana 1989; Christidou 1999, 2001; D’Errico 1993; Dobres 1995; Gates St-Pierre 2007; Griffitts 2001; Griffitts and Bonsall 2001; Legrand 2007; Legrand and Sidéra 2007; LeMoine 1997; Maigrot 1997, 2004; Martineau and Maigrot 2004; Meneses Fernandez 1994; Olsen 1988, 2001; Peltier and Plisson 1986; Semenov 1964; Sidéra 1989, 1993; Stordeur 1983; Stordeur and Christidou in press; Van Gijn 2005). The plasticity and softness of bone allow rapid and characteristic recording of a given action. The original volume of the active end of the tool is more or less quickly deformed depending on the way the tool is used, the nature of the material being worked, its condition, as well as the duration of use (Legrand and Sidéra 2007; Sidéra 1993). Smoothing, chipping, and crushing are the most common macroscopic wear processes that contribute to volume deformation. This deformation is accentuated by reshaping, which overlies wear traces.

With regard to microscopic wear, we refer to the methodology developed by Rozalia Christidou, which consists of a systematic examination of the surface at two magnifications $(100 \times$ and $200 \times)$ in order to assess use processes (Christidou 1999, 2001; Christidou and Legrand 2005; Legrand 2007; Stordeur and Christidou in press). The frequency, distribution, orientation, shape, and dimensions of the depressions of the entire surface determine the regularity or irregularity of the surface topography. When the surface shows slight differences, the topography is regular (Legrand 2007: fig. 29). The micro-relief is defined as a whole. Three types of micro-relief have been observed: irregular micro-relief with rough ridges (Legrand 2007: fig. 30, no. 1); homogeneous micro-relief, where ridges level off homogeneously (Legrand 2007: fig. 30 , no. 2); and regular micro-relief, where the ridges are completely smooth (Legrand 2007: fig. 30, No. 3). The aspect, texture, and brightness of each ridge are then defined. Ridges are rounded or flat, and their texture can be grainy or smooth depending on the frequency and the morphological variability of the micro-pits. Their brightness varies from matte to varnished. Different kinds of depressions can be observed on the surface. At the macroscopic level, the frequency, distribution, extension, orientation, morphology, and organization of the striations can be perceived. At the microscopic scale, we can distinguish fine striations (less than $1 \mu \mathrm{m}$ in width) from the broader ones. The aspect of the edges and bottoms can only be defined for the broader striations. The edges are angular or smoothed, and the bottoms are either rough, partially smoothed, or completely smoothed. Other depressions, called craters and micro-pits depending on their dimensions, suggest the high degree of surface modification. On- ly morphology, dimensions, and the aspects of the edges and bottoms of the craters can be characterized.

Two methods evaluating the development of wear can be used to make use-wear analysis systematic. The first method consists of evaluating the development of wear on each artifact, dividing the active part into different zones depending on the intensity of wear (Legrand and Sidéra 2007: figs. 13-14; Legrand 2007). The first zone of wear corresponds to the part of the tool most used; this zone is, thus, the most important for interpretation of tool function. The further one moves from this zone, the less the surface is worn. The second zone of wear is defined as an intermediate zone of friction, and the third zone is the least-worn. If only the first zone of wear is observed, the development of wear is homogenous, in comparison with the gradual development of wear when two or three zones are defined. Using this method, we can measure the extent of wear only if its limit is clear. Wear is measured from the active end of the tool toward the interior. The extent of wear can be marginal (up to $5 \mathrm{~mm}$ long), moderate (between 5 and $20 \mathrm{~mm}$ ), invasive (more than $20 \mathrm{~mm}$ ), and covering (the entire length of the tool is worn). The second method consists of identifying the different degrees of wear on tools from the same category. One can reconstruct the "chain of wear" (Sidéra and Giacobini 2002: fig. 10). In all cases, measuring the extent and nature of the wear along the tool surface permits us to make inferences about the intensity and the mode of tool use as well as the nature of the worked material.

\section{Replication and Use-Wear Analysis}

In order to relate wear traces to the function of the archaeological implements, it is necessary to experiment. It is difficult to acquire well-used tools that closely resemble the archaeological ones, which are heavily deformed because of intensive or long-term use (Choyke 2006). Ethnographic artifacts can be studied, but as their exact function and the duration of their use are not often precisely known, they are not always helpful. Our experimental bone tool assemblage consisted of more than 100 points, needles, edge tools, etc. (Legrand 2007). Different materials were worked-hide, leather, wood, bark, various plant fibers (flax, straw, reed, sedge grass), clay, and bone-with different modes of use and motions, different durations of use (from five minutes to five days), and two modes of gripping (hafted or un-hafted).

Our experimentation conducted on plant fibers began with sewing and weaving flax. In weaving, a thread of flax was run alternately behind and in front of vertical threads with a needle. The horizontal lines of threads were then pushed together using a point to tighten them (FIG. 3A). 

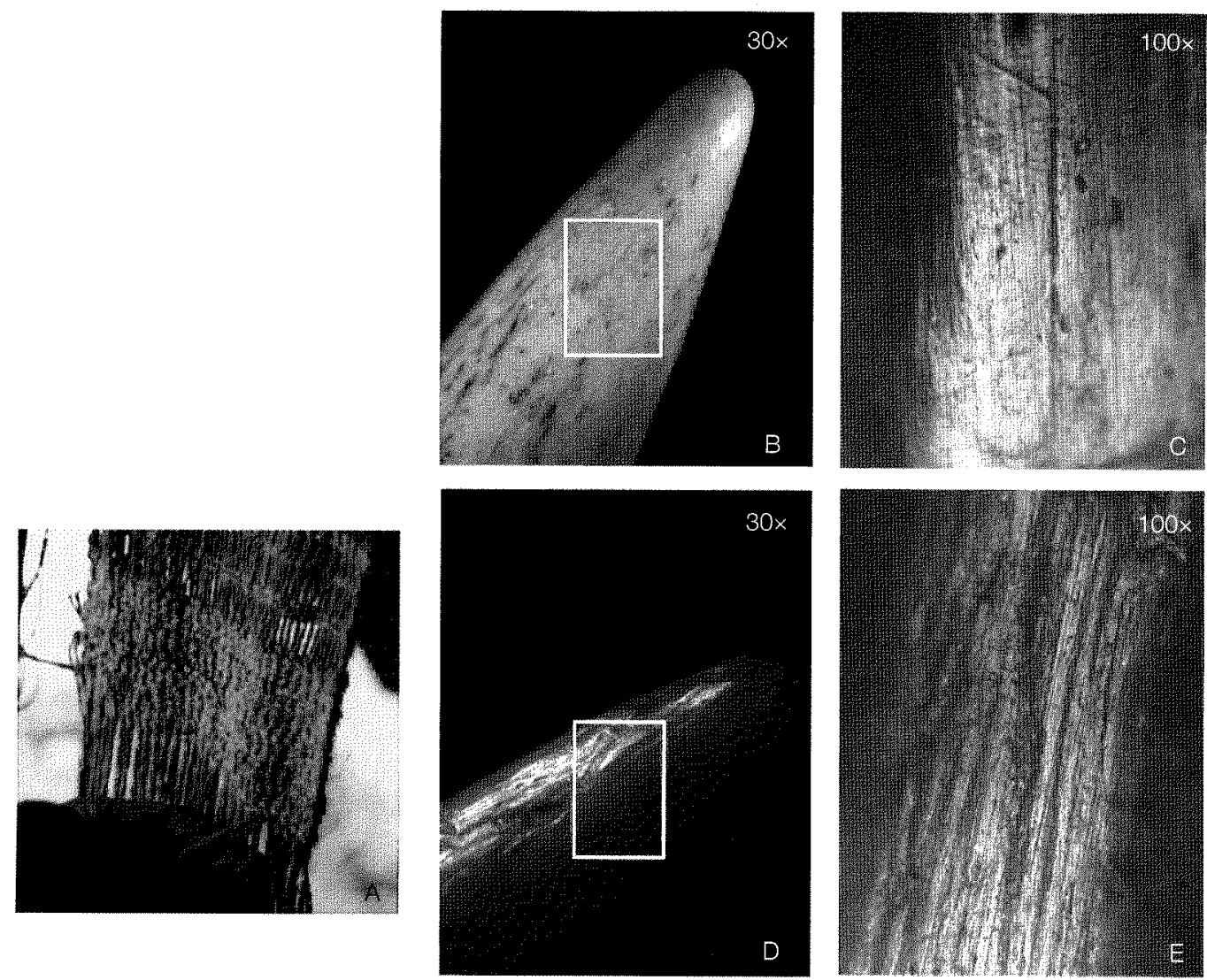

Figure 3. Use-wear patterns observed on an two experimental points used in weaving flax for 50 hours. A) Experimental; B, D) General view of the tips; C, E) Details of the use-wear pattern at $100 \times$ magnification. Experimentation and photograph by Alexandra Legrand.

Points and needles were used from 10 to 50 hours. The main effects of flax weaving on experimental points were as follows: moderate extent of wear; gradual development of wear; a smooth tip with localized chipping (FIG. $3 \mathrm{~B}, \mathrm{D}$ ); irregular or regular surface topography; homogeneous micro-relief with flat or domed ridges and grainy texture; numerous multi-directional, short, fine (less than $1 \mu \mathrm{m}$ ), superficial, straight, and continuous striations; and few craters (FIG. 3C, E).

Different techniques of basket-making exist, but according to ethnographic data it seems that spiral basketmaking is the only technique requiring a point or a needle to pass through a. strap that attaches the spirals together (Anquetil 1979: 161; Balfet 1952: 270; Mason 1984: 245; Miles 1963: 94). Various plants such as grasses, inner bark, reeds, rush (Juncus), or flax can be employed (Anquetil 1979: 159; Körber-Grohne 1991: 93-94; Miles 1963: 94). Our experiment was carried out by a basketmaker (Henriette Cazé) on sedge grass (Cyperaceae family), rye straw, and tor-grass (Poaceae family) (FIg. 4A). Points were manipulated longitudinally from 10 to 20 hours. In contrast to the wear observed on points used in flax weaving, the wear observed on points used in basketmaking was much more invasive and developed. This probably can be explained by more extensive contact with the worked material. The main differences are: a more pronounced smoothing of the tip, regular micro-relief (the surface is totally smoothed and varnished), numerous wellorganized striations (mainly longitudinal, tightened, fine or broad, superficial or deep), and numerous craters (FIGs. $4 \mathrm{~B}-\mathrm{D}, 5 \mathrm{~A}-\mathrm{C})$.

Bone points are typically referred to as perforating tools used to open holes in hides, pass thongs or threads through holes, or untangle knots of cords, thongs, and threads (Christidou and Legrand 2005). In our experiments, perforators were applied to fresh, wet, damp, tanned, and untanned hides in two ways: by indirect percussion or by rotation. When points were subjected to indirect percussion to punch holes, the hide was laid on a wooden plank, usually with a hide piece interposed between the plank and the worked hide. Points were used from 10 to 100 minutes. Indirect percussion and rotation can be distinguished 

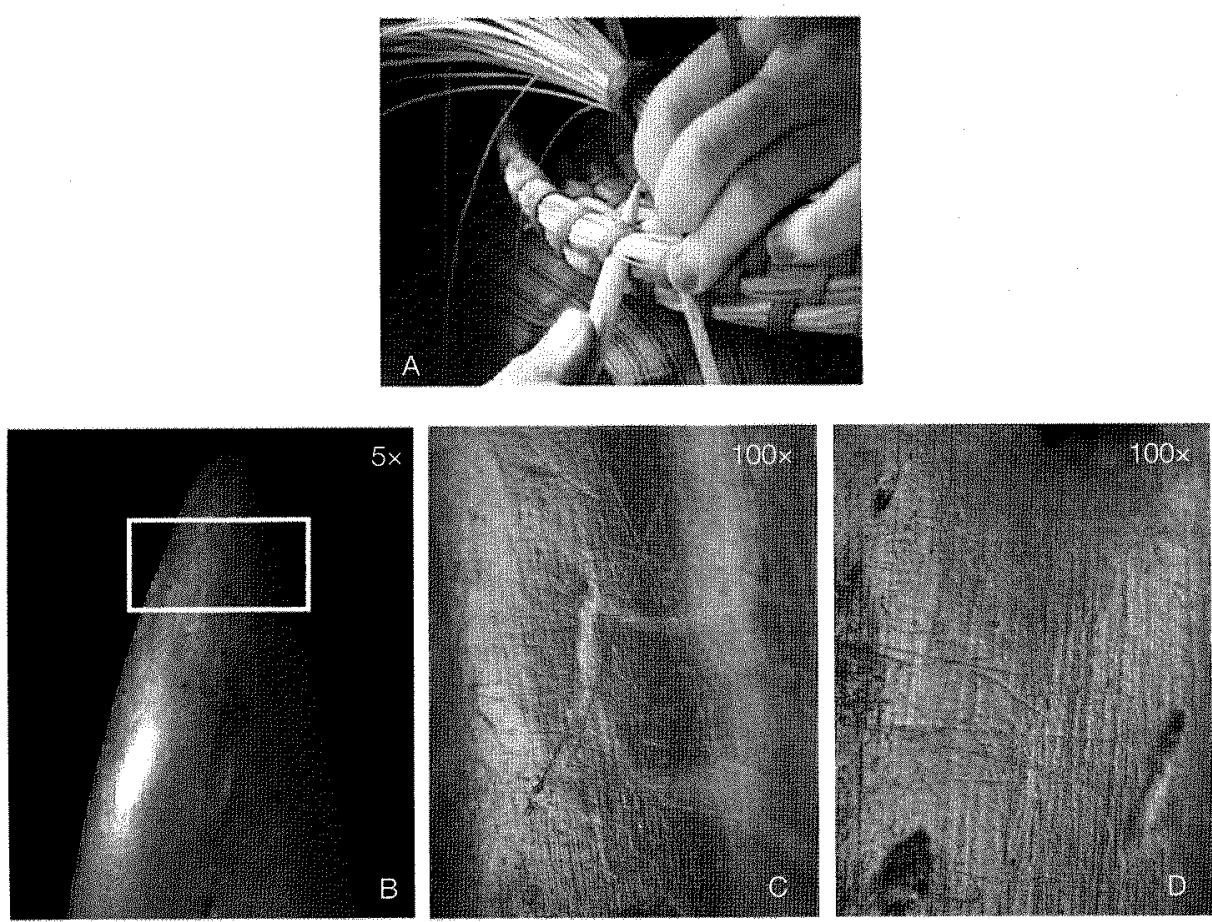

Figure 4. Use-wear patterns observed on an experimental point used on sedge grass in basketry for 15 hours. A) Experimental basket; B) General view of the tip; C-D) Details of the use-wear pattern at $100 \times$ magnification. Experimentation by Henrictte Cazé. Photographs by Alexandra Legrand.

when considering the deformation of tips and the development and orientation of the use striations on the active parts. On the tools used in indirect percussion on wet hides, the tips were usually smoothed and crushed (FIG. $6 \mathrm{~A})$. The wear consisted of a dense network of longitudinal, long, and continuous narrow dark striations covering the entire surface (FIG. 6B). Frequent non-linear, roughbottomed depressions occurred, as well as micro-pits. Ridges were worn down and smoothly rounded and had a grainy texture. On the tools rotated on wet hides, the tips were smoothed or slightly facetted. Striations were mainly longitudinal but in a less marked form, and transverse and oblique ones also occured. Otherwise, the nature of the striations and non-linear depressions, the presence of micro-pits, and the grainy texture of the relief were common features of tools subjected to either indirect percussion or rotated.

\section{Use-Wear Analysis on the Colle Santo Stefano Bone Points}

Fifty points from Colle Santo Stefano were selected for analysis on the basis of low levels of fragmentation and good surface preservation. We considered all the complete tools $(\mathrm{n}=23)$, and some distal fragments $(\mathrm{n}=27)$ which were sufficiently preserved. Three levels of preservation were established according to the legibility of macro- and micro-use wear: Level A: excellent $(n=9)$; Level $B$ : very $\operatorname{good}(\mathrm{n}=25)$; and Level C: $\operatorname{good}(\mathrm{n}=16)$. This sample includes two points from Type III (as described above), 35 points from Type IV, including 24 formally-worked points (Type IV-A) and 11 informally-worked points (Type IV-B), and 13 typologically undetermined fragments.

When possible, we measured the gauge of the point's tip by multiplying width and thickness at the spot with the maximum extent of wear. When the extent of wear could not be measured, we considered the original volume deformation of the active end, especially when the form of the tip was clearly marked from the rest of the tool, thus showing the length of penetration of the tip into the worked material (Legrand and Sidéra 2007: fig. 5). Three gauges were established: fine gauge, less than or equal to 20; middle gauge, between 21 and 45 ; and heavy gauge, equal to or higher than 46.

\section{Plant Working}

Twenty-one points from Colle Santo Stefano, including two points from Type III and 19 points from Type IV (11 Type IV-A and 8 Type IV-B), were interpreted as having been used on plants based on their use-wear features. Three main wear patterns were identified. In the first pattern, 

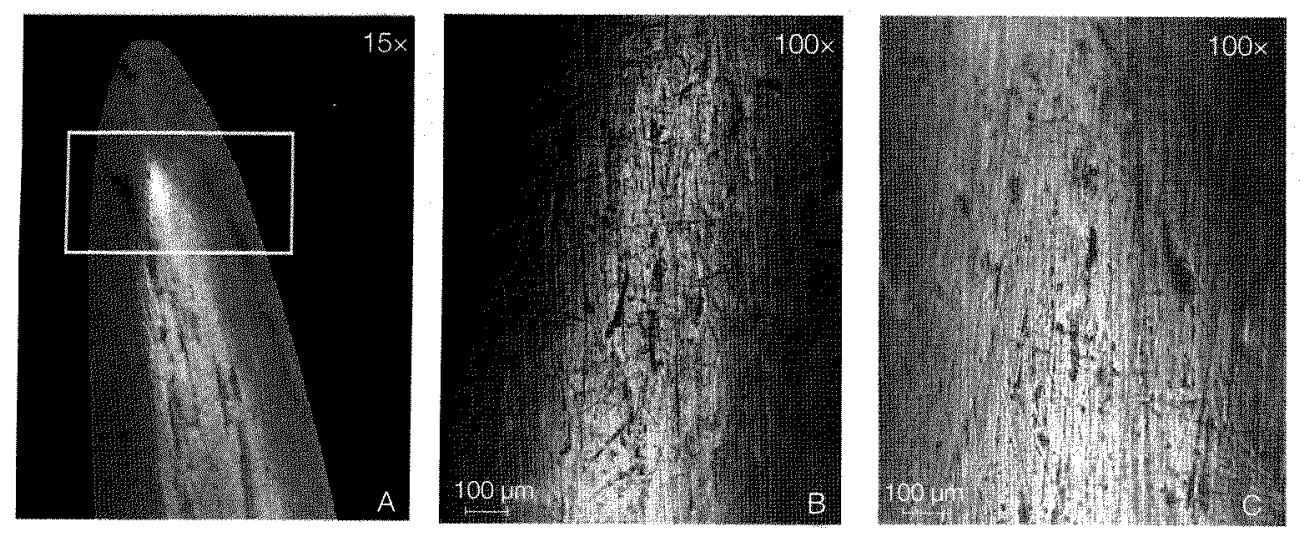

Figure 5. Use-wear patterns observed on an experimental point used on rye straw in basketry for 10 hours. A) General view of the tip; B-C) Details of the use-wear pattern at $100 \times$ magnification. Experimentation by Henriette Cazé. Photographs by Alexandra Legrand.
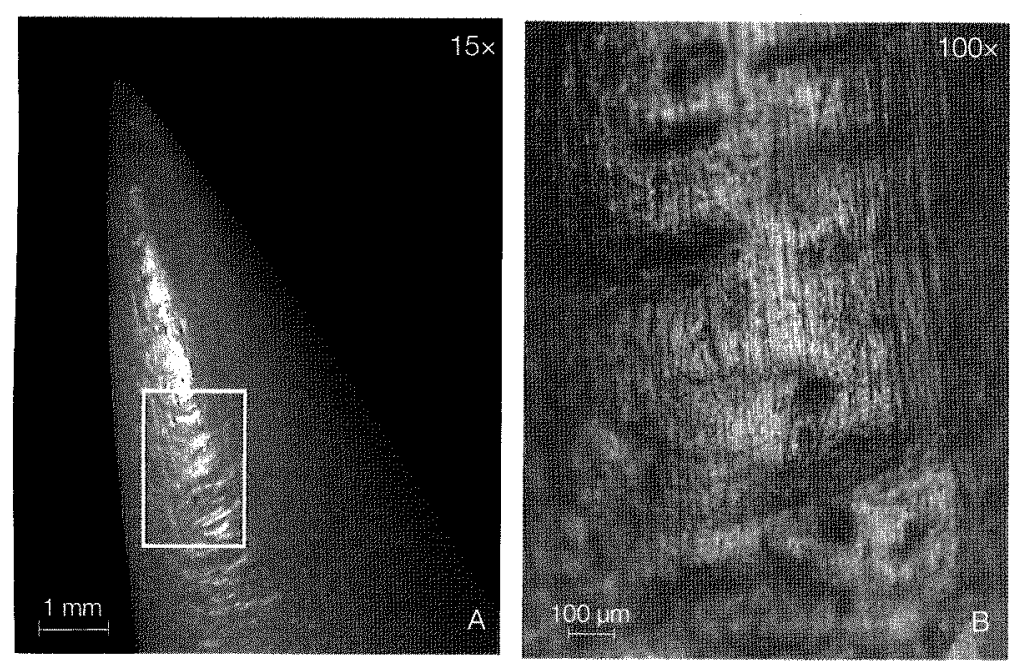

Figure 6. Use-wear patterns observed on an experimental point used to perforate fresh hide for 30 minutes. A) General view of the tip; B) Details of the use-wear pattern at $100 \times$ magnification. Experimentation and photograph by Alexandra Legrand.

shown by the two complete Type III points, the gauge is fine (less than 5 ) and there is invasive wear with homogenous development. One point displays a smooth tip (FIG. $7 \mathrm{~A})$ while the other is also smoothed but highly deformed by post-depositional chipping. Longitudinal, long and straight striations, as well as craters, are observed at the macroscopic level (FIG. 7B). At $100 \times$, the surface topography on both points is irregular and depressions of various sizes and morphologies were observed (FIG. 7C). The micro-relief appears regular for one point and homogeneous for the other. In the latter case, ridges are rounded and varnished and have a smooth texture. In both cases, most of the striations are longitudinal, fine or broad, par- allel or crossed. Fewer short ones are transverse and oblique. The edges of the broader striations are smoothed and their bottoms are rough or partially affected by wear. Numerous circular and oval craters were also observed. Their edges are smoothed and their bottoms are mainly rough. These craters must be distinguished from natural depressions called osteones which are characterized by concentric circles.

Four points from Type IV (including three from Type IV-A and one from type IV-B) show similar wear. These are two distal fragments and one complete tool. They all have a fine gauge. Their smoothed tips show moderate to invasive wear with homogeneous development (FIG. 7D, E). 

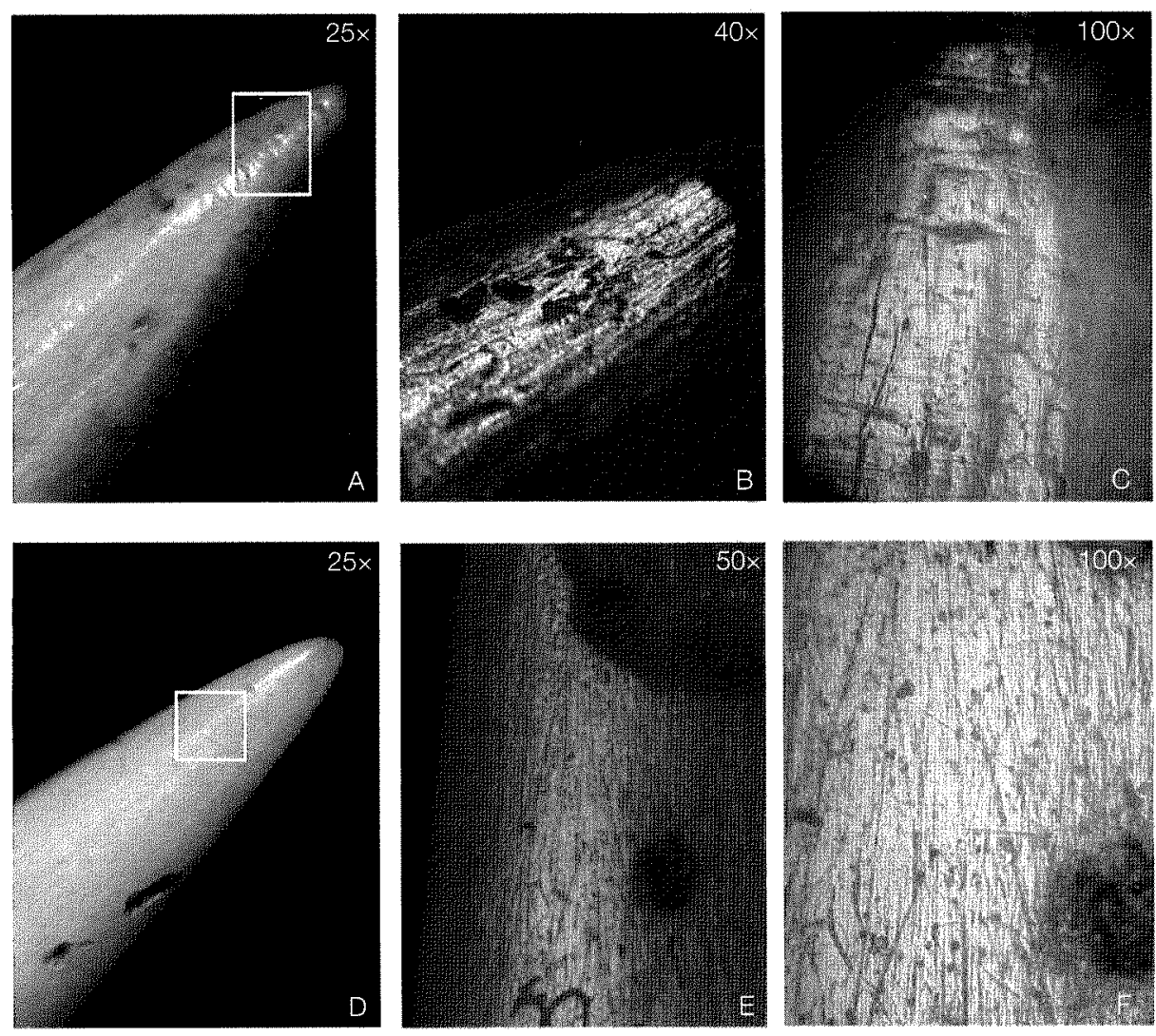

Figure 7. Two Colle Santo Stefano bone points showing plant working pattern number 1. A, D) General view of the deformation of the tip; B, E) Details of the macroscopic use-wear pattern; C,

F) Details of the use-wear pattern at $100 \times$ magnification. Photographs by Alexandra Legrand.

Only one point from Type IV-A was reshaped on its distal end. Numerous rough-bottomed circular craters and striations are scattered on the surface, which thus appears irregular (FIG. 7F). The micro-relief is regular and the striations appear mostly broad and deep. These are multidirectional but mainly longitudinal, short or long, and straight. Thus, we can suggest that the motion was longitudinal. A gripping wear pattern is identified on the proximal end of one tool which shows that the point was handled directly.

When compared to experimental examples, all of these points seem to have been rotated on plant fibers or used with a longitudinal motion. The characteristics of the topography and the micro-relief, specifically the texture and the brightness of the ridges and the presence of numerous craters, are general features we can observe on implements used for plant working. Though the nature of the plants remains undetermined, it must be stressed that the transverse grinding striations are partially or highly smoothed which means that the plants should have been relatively soft to affect the bottom of the broader depressions. The invasive extent of the wear and the smoothed tip are additional attributes in support of this hypothesis. Moreover, the aspect of the micro-relief and the presence of numerous craters suggest the use of highly abrasive plant parts such as woody fibers, leaves, or straw. Experimental points used in basket-making on rye straw over 10 hours display similar wear: irregular topography, regular microrelief, numerous rough-bottomed craters, and the same orientation and organization of striations (FIG. 5). Some differences can be seen between both patterns, however, and can be explained by the nature of the fibers, the motion, or the length of use. In particular, we observe that in the case of the experimental tools, striations appear thinner and tighter, and shorter striations are more frequent.

The second pattern concerns 10 points from Type IV (6 from Type IV-A, and 4 from Type IV-B). Six points are complete and four points are distal fragments. Their tips are mainly fine $(\mathrm{n}=7)$, and most have smoothed tips (FIG. $8 \mathrm{~A}, \mathrm{D})$. Longitudinal and long striations as well as craters are observed at the macroscopic level (FIG. 8B, E). The topography of the surface is irregular $(\mathrm{n}=6)$ or regular $(\mathrm{n}$ $=4)$. The micro-relief is regular $(n=6)$, or homogeneous 

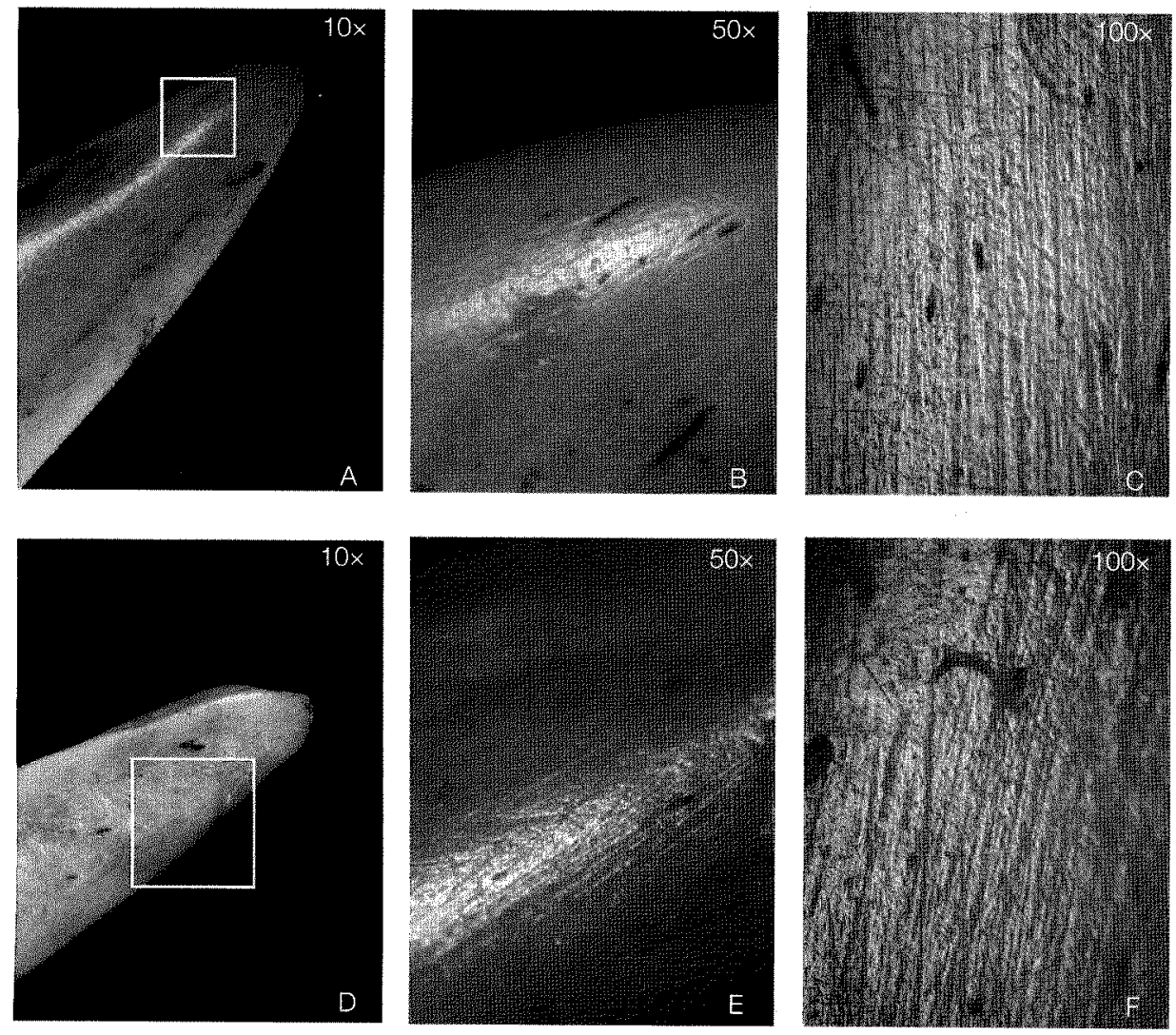

Figure 8. Colle Santo Stefano bone point showing plant working pattern number 2. A, D) General view of the deformation of the tip; B, E) Details of the macroscopic use-wear pattern; C, F) Details of the use-wear pattern at $100 \times$ magnification. Photographs by Alexandra Legrand.
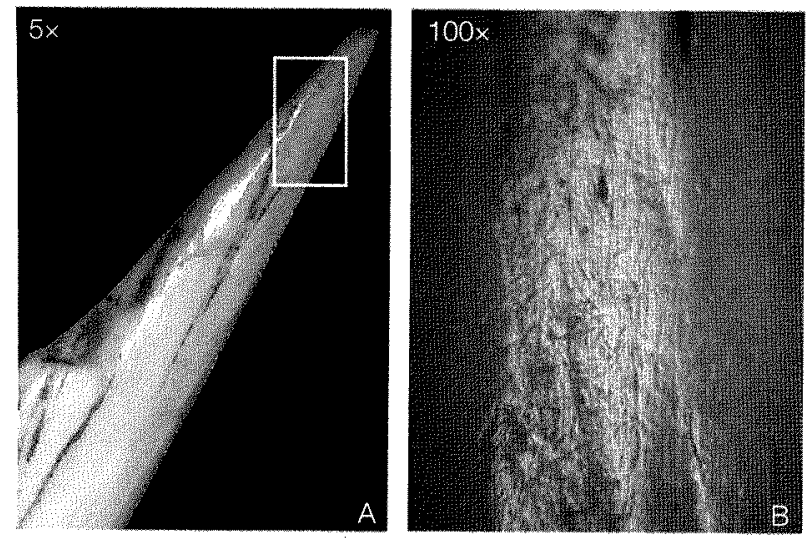

Figure 9. Colle Santo Stefano bone point showing plant working pattern number 3. A) General view of the deformation of the tip; B) Details of the use-wear pattern at $100 \times$ magnification. Photographs by Alcxandra Legrand.

$(n=4)$. In the latter case, the ridges are mostly rounded and varnished and have a grainy texture. Numerous longitudinal, long, straight, tightened, deep, and large striations are observed (FIG. 8C, F). They are parallel or crossed with smoothed edges and have rough or partially smoothed bottoms. Fewer striations are oblique or transverse. Few rough-bottomed craters are observed. The orientation of the striations indicates that these points were used with a 

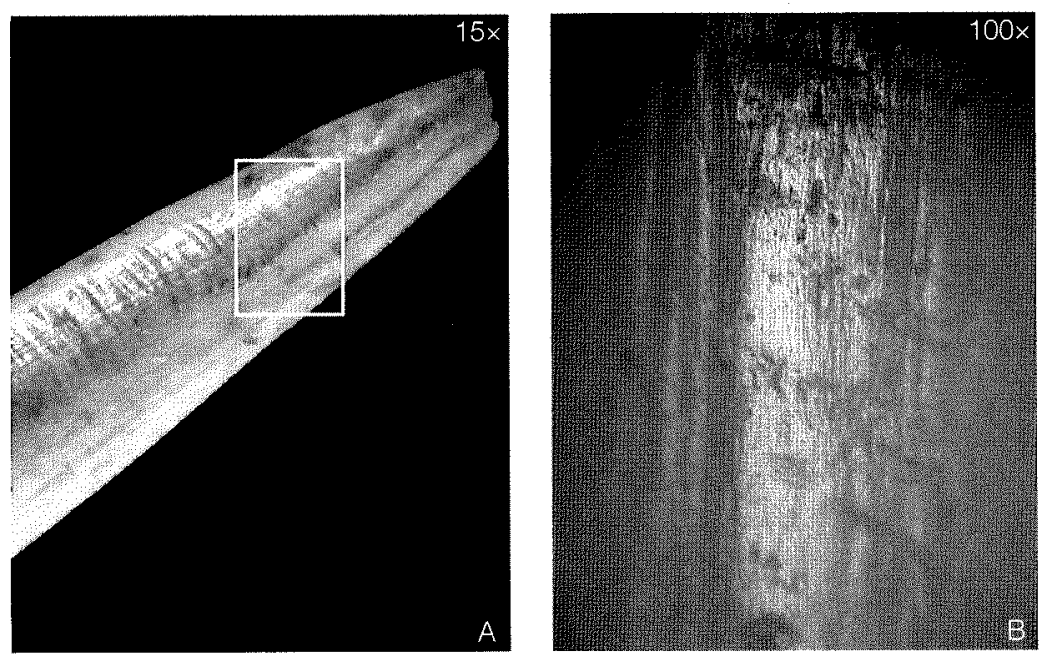

Figure 10. Colle Santo Stefano bone point used in hide working. A) General view of the deformation of the tip (post depositional chipping); B) Details of the use-wear pattern at $100 \times$ magnification. Photographs by Alexandra Legrand.

longitudinal motion. Thus, we suggest that they were pushed through the fibers, as there is no trace of percussion on the proximal end of these tools. Similarities are observed between these points and the experimental implements used in basketry on sedge grass for over 15 hours, particularly in the texture of the ridges and the general features of the striations (FIG. 4).

A third pattern was observed on three Type IV-B points and on two Type IV-A points. Three are fragments and two are complete. Their tips are mainly fine $(\mathrm{n}=3)$ and all are smoothed. In two cases, this smoothing is combined with chipping (FIG. 9A). Longitudinal, long, and straight striations are observed at the macroscopic level. The surface presents a regular topography in all cases. The micro-relief is homogeneous $(\mathrm{n}=3)$, regular $(\mathrm{n}=1)$, or homogeneous to regular $(\mathrm{n}=1)$. When the micro-relief is homogeneous, the ridges are mostly rounded or flat, varnished, and with a smoothed texture. At the microscopic level, striations appear fine, superficial, organized, parallel, and tightened (FIG. 9B). Fewer are broad with smoothed edges and partially smoothed bottoms. Craters are rare. The orientation of the striations indicates that these points were pushed through the fibers with a longitudinal motion; this is reinforced by the fact that gripping wear is observed on the proximal end of one tool. Use-wear appears different from that described above. The topography is regular, the texture of the ridges is smooth, the striations are mainly fine and superficial, and craters are rare. These features suggest that the plants were flexible. The nature of the fibers is undetermined, but the wear is similar to that on the experimental bone points used for tor-grass basketry and in flax weaving and sewing (FIG. 3). Several activities relating to basket-making, or the manufacture of clothes, ropes, mats, and so on, are thus possible. The use of flax remains a hypothesis, even though no seeds have yet been found at Colle Santo Stefano as the analysis of the botanical remains is not finished.

It must be stressed that these plant-working patterns occur on all types of points. Dimensions of points from Type III and Type IV are quite similar, and fine tips were manufactured preferentially. Nevertheless, points from Type IV-A display more invasive wear (half of the Type IVA points) compared to points from Type IV-B (one-eighth of the points). We can thus suggest that even if the nature of the fibers and the mode of use of the point are the same, they could have been used at different stages of manufacturing these fiber objects.

\section{Hide Working}

Two points from the archaeological assemblage, one complete Type IV-A point and one distal fragment, were interpreted as having been used on hide. The tip gauge could not be measured. The extent of wear is moderate or invasive and its development is gradual. Smoothing is the only macro-wear observed on the tip (FIG. IOA). Longitudinal, long, and straight striations as well as craters are highlighted at the macroscopic level. At $100 \times$, the surface topography on both points is regular (FIG. IOB). The micro-relief appears irregular for one point and homogeneous for the other. Ridges are rounded and varnished and have a grainy texture. Striations are numerous, longitudinal, fine or broad, and parallel. Few are oblique. The edges 
of the broader striations are smoothed and their bottoms are rough. Some circular rough craters and micro-pits are also observed. The orientation of the striations indicates that these points were rotated. Experimental replication suggests that these points were used to perforate fresh hides (FIG. 6).

\section{Conclusions}

One of the main features of the Colle Santo Stefano bone point assemblage is that the majority of tools made from blanks do not have preserved and diagnostic anatomical characteristics ( 81 out of 96 points typologically determined). Contrary to what is commonly observed in other bone industries from the Early Neolithic period, points made from halved metapodials with the distal epiphyses partially preserved are found infrequently at Colle Santo Stefano. Another feature of this assemblage is the presence of a considerable number of formally-worked points $(\mathrm{n}=$ 45). These points do not seem to have had a specific function, as we originally thought. Instead, they were probably used for working with various plants in different activities such as weaving and basket-making, and to a lesser extent, with hides.

Several hypotheses can be proposed regarding the technical investment in these formally-worked points. Individual variability could have resulted from the degree of specialization of the artisans. As Gaëlle Le Dosseur proposed (2006), the simplest and most expedient production requiring no particular technical skill would be undertaken by less experienced workers or by younger members of the group, and the more carefully worked implements would be manufactured by experienced artisans. Conversely, nontechnical investment considerations might include the opportunistic choice of a blank according to bone availability, the time available for tool manufacture, or according to need. Finally, following Alice Choyke (2006), the care given to their shaping and reshaping, when compared to other types of points, suggests a special value was attributed to the points which may have denoted the identity and/or degree of specialization of the artisan and also the identity of the community.

\section{Acknowledgments}

This project was supported financially by a post-doctoral scholarship from the Singer-Polignac Foundation (Paris, France). Fabiana Coli was responsible for identifying the source taxon and part (suid vertabra) of the point described in the Bone Point Types (Type II) section of this paper. Lucio Calcagnile from the Dating and Nuclear Diagnostic Center of the University of Lecce produced seven radiocarbon dates, and Gilberto Calderoni from the Depart- ment of Earth Sciences of the University of Rome provided one additional radiocarbon date.

Alexandra Legrand (Ph.D. 2005, University of Paris I Pantheon-Sorbonne) is interested in bone technology and use-wear analysis of Neolithic industries, processes of neolithization in the western Mediterranean (Italy, southern France, and Spain), the effect of insularity on the elaboration and evolution of bone industries (especially in the Cypriot aceramic and ceramic Neolithic periods), and neolithization processes in South Asia (Baluchistan, Pakistan). Mailing address: CNRS-UMR 7055, "Préhistoire et technologie," Maison de l'Avchóologiv et de l'Ethnologie René Ginouvès, 21 Allée de l'Université, 92000 Nanterre, France. E-mail: alexan-

dra.legrand@mae.u-parislo.fr

Giovanna Radi (Ph.D. 1971, University of Pisa) is a Professor in the Dipartimento di Scienze Archeologiche at the University of Pisa. Her research interests are Early Neolithic lithic industries, neolithization processes in southern Italy, evolution of the Neolithic in Tuscany and the Abruzzo, the acquisition of obsidian as a raw material during the Neolithic in Italy, and the characterization of Bronze Age material culture in Tuscany and the Abruzzo. Mailing address: Dipartimento di Scienze Archeologiche, Università di Pisa, Via Santa Maria 53, 56126 Pisa, Italy. E-mail: radi@arch.unipi.it

Anquetil, Jacques

1979 La vannerie. Paris: Encyclopédie contemporaine des métiers d'art, Dessain et Tolra/chêne Edition.

Balfet, Hélène

1952 "La vannerie, essai de classification," L'Anthropologie 56: 259-280.

Buc, Natacha, and Daniel Loponte

2007 "Bone Tool Types and Microwear Patterns: Some Examples from the Pampa Region, South America," in Christian Gates St-Pierre and Renee Walker, eds., Bones as Tools: Current Methods and Interpretations in Worked Bone Studies. BAR Intemational Series 1622. Oxford: B. A. R., I43-157.

Campana, Douglas V.

1989 Natufian and Protoneolithic Bone Tools. The Mamufacture and Use of Bone Implements in the Zagros and the Levant. BAR Intemational Series 494. Oxford: B. A. R.

Camps-Fabrer, Henriette, and André D'Anna

1977 "Fabrication expérimentale d'outils à partir de métapodes de mouton et de tibias de lapin," in Henriette Camps-Fabrer, ed., Méthodologie appliquée à lindustrie de l'os prébistorique. Deuxieme colloque international sur lindustrie de l'os dans la Prébistoire, Abbaye de Sénanque, juin 1976. Paris: Editions du CNRS, 311-323.

Castiglioni, Elisabetta, and Mauro Rottoli

2003 "Nuovi dati archeobotanici per la preistoria dell'Abruzzo," in Atti XXXVI Rinnione Scientifica Istituto Italiano di Preistoria e Protostoria, Chieti-Celano 27-30 settembre 2001. Firenze: Instituto italiano di preistoria e protostoria, $657-661$. 
Choyke, Alice M.

2006 "Bone Tools for a Lifetime: Experience and Belonging" in Laurence Astruc, François Bon, Vanessa Léa, Pierre-Yves Milcent, and Sylvie Philibert, eds., Normes Techniques et Pratiques Sociales: De la simplicité des outillages pré-et protobistoriques, XXVI Rencontres Internationales et d'Histoire d'Antibes. Antibes: CÉPAM, 49-60.

Choyke, Alice M., and Jörg Schibler

2007 "Prehistoric Bone Tools: Research in Central Europe," in Christian Gates St-Pierre and Renee Walker, eds., Bones as Tools: Current Methods and Interpretations in Worked Bone Studies. BAR Intemational Series 1622. Oxford: B. A. R., $51-65$.

Christidou, Rozalia

1999 "Outils en os néolithique du nord de la Grèce: étude technologique," unpublished Ph.D. dissertation, University of Paris X, France.

2001 "Usure frontale d'un outil tranchant en os: deux mouvements opposés, une séquence technique?" in Laurence Bourguignon, Iluminada Ortega, and Marie-Chantale Frère-Sautot, eds., Préhistoive et approche expérimentale, Préhistoire 5. Montagnac: Editions Monique Mergoil, 259-264.

2004 "Fabrication d'outils en os. Exemple d'opérations de raclage et d'abrasion," Les Dossiers d'Archéologie 290: 56-57.

Christidou, Rozalia, and Alexandra Legrand

2005 "Hide Working and Bone Tools: Experimentation Design and Applications," in Heidi Luik, Alice M. Choyke, Colleen E. Batey, and Lembi Lóngas, eds., From Hooves to Horns, from Mollusc to Mammoth, Manufacture and Use of Bone Artefacts from Prehistoric Times to the Present. Proceedings of the 4th Meeting of the ICAZ Worked Bone Research Group, Tallinn 26-31 August 2003. Tallinn: Muinasaja teadus 15, 385-396.

Coli, Fabiana

2002 "Analisi tipologica e tecnologia di manufatti in materia dura animale. Lesempio del sito neolitico di Santo Stefano (Abruzzo, Italia) a confronto con altri manufatti," unpublished M.A. thesis, University of Pisa, Italy.

Cremonesi, Giuliano

1976 La Grotta dei Piccioni di Bolognano nel quadro delle culture dal neolitico all'età del bronzo in Abruzzo. Pisa: Collana di Studi Paletnologici, Giardini.

D'Errico, Francesco

1993 "Identification des traces de manipulation, suspension, polissage sur l'art mobilier en os, bois de cervidé, ivoire," in Patricia Anderson, Sylvie Beyries, Marcel Otte, Hugues Plisson, eds., Traces et fonction, les gestes retrouvés. Actes du colloque international de Liège, décembre 1990 Vol. 1. ERAUL 50. Liège: Université de Liège, 177-188.

Dobres, Marcia-Anne.

1995 "Gender and Prehistoric Technology: On the Social Agency of Technical Strategies,".World Archacology 27: 25-49.

2000 Technology and Social Agency: Outlining a Practice Framework and Social Agency. Oxford: Blackwell Publishers.

ETTOS

1985 "Technique de percussion appliquée aux matériaux osseux, premières expériences," Cahiers de l'Euphrate 4: 373-381.

Fabbri, Cristina

2006 "Linsediamento di Colle Santo Stefano (Bacino del Fuci- no, AQ): studio tipologico e tecnologico della ceramica," unpublished Ph.D. dissertation, University of Siena, Italy.

Fugazzola Delpino, Maria-Antonietta, Andrea Pessina, and Vicenzo Tiné

2002 Le ceramiche imprese nel neolitico Antico, Italica e Mediterraneo. Roma: Instituto Poligrafico e Zecca dello Stato.

Gates St-Pierre, Christian

2007 "Bone Awls of the St. Lawrence Iroquoians: A Microwear Analysis," in Christian Gates St-Pierre and Renee B. Walker, eds., Bones as Tools: Current Methods and Interpretations in Worked Bone Studies. BAR International Series 1622. Oxford: B. A. R., 107-118.

Griffitts, Janet

2001 "Bone Tools from Los Pozos," in Alice M. Chovke and László Bartosiewicz, eds., Crafting Bone-Skeletal Technologies Through Time and Space: Proceedings of the 2nd Meeting of the (ICAZ) Worked Bone Research Group. BAR International Series 937. Oxford: B. A. R., 185-196.

Griffitts, Janet, and Clive Bonsall

2001 "Experimental Determination of the Function of Antler and Bone 'Bevel-Ended Tools' from Prehistoric Shell Middens in Western Scotland,' in Alice M. Choyke and László Bartosiewicz, eds., Crafting Bone-Skeletal Technologies Through Time and Space: Proceedings of the 2 nd Meting of the (ICAZ) Worked Bone Research Group. BAR International $S_{e-}$ ries 937 . Oxford: B. A. R., 209-222.

Körber-Grohne, Udelgard

1991 "The Determination of Fibre Plants in Textiles, Cordage, and Wickerwork," in Jane M. Renfrew, ed., New Light in Early Farming, Recent Developments in Palacoethnobotany. Edinburgh: Edinburgh University Press, 93-104.

Le Dosseur, Gaëlle

2006 "La fabrication et l'entretien des poinçons en os au Levant sud: investissement technique et règles de productions du Natoufien au néolithique précéramique B récent," in Laurence Astruc, François Bon, Vanessa Léa, Pierre-Yves Milcent, and Sylvie Philibert, eds., Nomes Techniques et Pratiques Sociales: De la simplicité des outillages pré- et protohistoriques, XXVI Rencontres Internationales et d'Histoire d'Antibes. Antibes: CÉPAM, 345-357.

Legrand, Alexandra

2007 Fabrication et utilisation de l'outillage en matieres asseuses du Néolithique de Chypre: Khirokitia et Cap Andreas-Kastros. BAR International Series 1678. Oxford: B. A. R.

Legrand, Alexandra, and Isabelle Sidéra

2007 "Methods, Means, and Results When Studying European Bone Industry" in Christian Gates St-Pierre and Renee Walker, eds., Bones as Tools: Current Methods and Interpretations in Worked Bone Studies. BAR International Series 1622 Oxford: B. A. R., 67-80.

LeMoine, Genevieve

1997 Use Wear on Bone and Antler Tools from the Mackensie Inuit. BAR International Series 679. Oxford: B. A. R.

Lollini, Delia G.

1991 Museo Archeologico Nazionale delle Marche, Sezione preistorica. Paleolitico-Neolitico. Falconara: Errebi.

Maigrot, Yolaine

1997 "Tracéologie des outils tranchants en os des Ve et IVe millénaires av. J.-C. en Bassin parisien. Essai méthodologique et application," Bulletin de la société préhistorique friangaise 94 (2): 198-216. 
2004 "Les outils en matières dures animales utilisés pour le travail du bois à Chalain station 4 (Néolithique final, Jura)," in Pierre Bodu and Claude Constantin, eds., Approches fonctionnelles en Préhistoire. Actes du XXVe Congrès Préhistorique de France, Nanterre 24-26 Novembre 2000. Paris: Société Préhistorique Française, 67-82.

Martineau, Rémi, and Yolaine Maigrot

2004 "Les outils en os utilisés pour le façonnage des poteries néolithiques de la station 4 de Chalain (Jura, France)," in Pierre Bodu and Claude Constantin, eds., Approches fonctionnelles en Prébistoire. Actes du XXVe Congrès Préhistorique de France, Nanterve 24-26 Novembre 2000. Paris: Société Préhistorique Française, 83-96.

Mason, Otis T.

1984 Aboriginal American Indian Basketry, Studies in a Textile Art Without Machinery. Glorieta, NM: Rio Grande Press.

Meneses Fernández, Maria D.

1994 "Útiles de hueso del Neolítico final del sur de la Península Ibérica empleados en alfarería: placas curvas, biseles, placas y apuntados," Trabajos de Prehistoria 51 (1): 143-156.

Miles, Charles

1963 Indian and Eskimo Artefacts of North America. New York: Bonanza Books.

Newcomer, Mark

1974 "Study and Replication of Bone Tools from Ksar Akil (Lebanon)," World Archaeology 6: 138-153.

Olsen, Sandra A.

1988 Scanning Electron Microscopy in Archaeology. BAR International Series 452. Oxford: B. A. R.

2001 "The Importance of Thong-smoothers at Botai, Kazakhstan," in Alice M. Choyke and László Bartosiewicz, eds., Crafting Bone, Skeletal Technologies through Time and Space. Proceedings of the 2nd meeting of the Worked Bone Research Group (ICAZ), 31 August-5 September 1999, Budapest. BAR International Series 937. Oxford: B. A. R., 197-206.

Peltier, Aurélia

1986 "Etude expérimentale des surfaces osseuses façonnées et utilisées," Bulletin de la société préhistorique française 83 (1): $5-7$.

Peltier, Aurélia, and Hugues Plisson

1986 "Micro-tracéologie fonctionnelle sur l’os, quelques résultats expérimentaux," in Emiliano Aguirre and Marylène Patou-Mathis, eds., Outillage peu élaboré en os et en bois de cervidés, 3ème réunion du groupe de travail $N^{\circ} 1$, Artefact 3 . Treignes: Editions du Centre d'Etudes et de Documentation Archéologiques, 69-80.

Radi, Giovanna

1991 "Il villaggio neolitico di Colle Santo Stefano (Ortucchio)," in Umberto Irti, Giuseppe Grossi, and Carmine Malandra, eds., Il Fucino e le aree limitrofe nell'Antichità. Atti Convegno di Archeologia, Apezzano 10-11 nopember 1989. Roma: Archeoclub della Marsica, 110-121.

1996 "Osservazioni sulla Ceramica Impressa abruzzese-marchigiana," in Miscellanea in memoria di Giuliano Cremonesi. Pisa: ETS Edition, 129-156.

Radi, Giovanna, and Ermanno Danese

2003 "Labitato di Colle Santo Stefano di Ortucchio (L'Aquila)," in Preistoria e Protostoria dell'Abruzzo. Atti XXXVI Riznione Scientifica Istituto Italiano di Preistoria e Protostoria, ChietiCelano 27-30 settembre 2001. Firenze: Instituto italiano di preistoria e protostoria, 145-161.
Radi, Giovanna, and Barbara Wilkens

1989 "Il sito a ceramica impressa di Santo Stefano (Ortucchio, L'Aquila)," Rassegna di Archeologia 8: 97-117.

Radi, Giovanna, Giovanni Boschian, L. Calani, A. Pistoia, and Barbara Zamagni

2001 "Nuovi dati dal villaggio a ceramica impressa di Colle Santo Stefano (Ortucchio)," in Umberto Irti, Giuseppe Grossi, and Carmine Malandra, eds., Il Fucino e le aree limitrofe nell'Antichità. Atti del II Convegno di Archeologia, Museo di Preistoria, Celano-Paludi 26-28 november 1999. Roma: Archeoclub della Marsica 70-81.

Schibler, Jörg

1981 Typologische Untersuchungen der cortaillodzeitlichen Knochenartefakte. Bern: Die neolitischen ufersiedlungen von Twann, Bd 17.

Semenov, Sergei A.

1964 Prehistoric Technology. London: Cory, Adam, and Machay.

Sidéra, Isabelle

1989 Un complément des données sur les sociétés rubanées: Pindustrie osseuse à Cuiry-lès-Chaudardes. BAR International Series 520. Oxford: B. A. R.

1993 "Les assemblages osseux en bassins parisien et rhénan du VIe au IVe millénaire B.C. Histoire, techno-économie et culture," unpublished Ph.D. dissertation, University of Paris I, France.

1996 "Rapport d'étude de l'assemblage osseux de Drama (Bulgarie)," in Jean Lichardus, ed., Bericht über die bulgarischDeutschen Augrabunger in Drama (1989-1995). Bericht der Rönisch-Germanischen Kommission, Deutsches Arcluäologisches Institut. Berlin: Von Zabern, Mainz am Rhein 77, 120-129.

2000 "Animaux domestiques, bêtes sauvages et objets en matières animales du Rubané au Michelsberg. De l'économic aux symboles, des techniques à la culture," Gallia Préhistoive 42: 107-194.

2004 "Exploitation de l'os au Néolithique dans les basins parisien et rhénan," in Denis Ramseyer, ed., Matières et techniques Cahier XI. Fiche de la Commission de nomenclature sur lindustrie de los préhistorique. Paris: Edition de la Société Préhistorique Française, 163-171.

Sidéra, Isabelle, and Giacomo Giacobini

2002 "Outils, armes et parures en os funéraires à la fin du Néolithique, d'après Val-de-Reuil et Porte-Joie (Eure)," Gallia Prébistoire 44: 215-230.

Skeates, Robin, and Ruth Whitehouse

1994 Radiocarbon Dating and Italian Prehistory. Rome: British School at Rome.

Stordeur, Danielle

1978 "Proposition de classement des objets en os selon le degré de transformation imposé à la matière première," Bulletin de la Société Prébistorique Française 75 (1): 20-23.

1983 "Quelques remarques pour attirer l'attention sur l'intérêt d'une recherche commune entre tracéologues du silex et technologues de l'os," in Marie-Claire Cauvin, ed., Traces d'utilisation sur les outils néolitbiques du Proche Orient. Lyon: Travaux de la Maison de l'orient 5, 231-240.

Stordeur, Danielle, and Rozalia Christidou

in press "L'industrie osseuse de Mureybet: étude morpho-technique et fonctionnelle," in Juan José Ibañez-Estevez, ed., 
Hommage à J. Cauvin. Le tell de Mureybet (Syrie du Nord) BAR International Series. Oxford: B. A. R.

Van Gijn, Amelou

2005 "A Functional Analysis of Some Late Mesolithic Bone and Antler Implements from the Dutch Coastal Zone," in Heidi Luik, Alice M. Choyke, Colleen E. Batey, and Lembi Lóugas, eds., From Hooves to Horns, from Mollusc to Mammoth, Manufacture and $U_{s e}$ of Bone Artefacts from Prehistoric Times to the Present, Proceedings of the 4th Meeting of the ICAZ Worked Bone Research Group, Tallinn 26-31 August 2003. Tallinn: Muinasaja teadus $15,47-66$.

Wilkens, Barbara

1991 "Resti faunistici ed economia preistorica nel bacino del Fucino", in Umberto Irti, Giuseppe Grossi, and Carmine Malandra, eds., Il Fucino e le aree limitrofe nell'Antichità. Atti Convegno di Archeologia, Avezzano 10-11 november 1989. Rome: Archeoclub della Marsica, 147-153. 